\title{
REKONSTRUKSI SENI LUKIS WAYANG KOPANG BERBASIS SENI RUPA HINDU
}

Oleh:

\author{
I Nyoman Putra Adnyana, I Kadek Sumadiyasa, I Ketut Suwidiarta \\ putraadnyana@unhi.ac.id, sumadiyasaseni@gmail.com, ketut_suwidiarta@yahoo.com
}

Program Studi Pendidikan Seni Rupa dan Ornamen Hindu, Fakultas Pendidikan

Universitas Hindu Indonesia Denpasar

Proses Review 5 Agustus-10 September, Dinyatakan Lolos 15 September

\begin{abstract}
The Wayang Kopang Painting Art at the Kopang Studio, Kerambitan Village, Tabanan Regency is a form of educational works of art and very unique Hindu ornaments that have been passed down from generation to generation. In its development, the art of painting experienced a downturn, so that there were efforts to revive it. This article will discuss the deconstruction of Wayang Kopang painting and its forms of deconstruction. This research aims at scientific development, dissemination of intellectual property research results and building academic scientific traditions. The research method is qualitative, data is collected through observation and interviews. Based on data collection and analysis, the results obtained were the reconstruction of wayang kopang painting based on several reasons, namely education, economy, identity, preservation and aesthetics. The form of reconstruction is following the times, adapting to a cultural village and using Wayang Kopang painting as a medium to strengthen sradha and devotion.
\end{abstract}

Keywords: reconstruction, wayang kopang, hindu

\section{Abstrak}

Seni Lukis Wayang Kopang di Sanggar Kopang Desa Kerambitan Kabupaten Tabanan merupakan salah satu wujud karya pendidikan seni rupa dan ornamen Hindu yang sangat unik yang diwarisi secara turun temurun. Dalam perkembangannya seni lukis ini mengalami keterpurukan, sehingga ada upaya untuk membangkitkannya. Artikel ini akan membahas tentang dekonstruksi seni lukis wayang kopang dan bentuk-bentuk dekonstruksinya. Penelitian ini bertujuan untuk pengembangan keilmuan, desiminasi hasil penelitian kekayaan intelektual serta membangun tradisi ilmiah akademik. Metode penelitian bersifat kualitatif, data dikumpulkan melalui observasi dan wawancara. Berdasarkan pengumpulan data dan analisis, didapatkan hasil yakni rekonstruksi seni lukis wayang kopang didasari atas beberapa alasan yakni pendidikan, ekonomi, identitas, pelestarian dan estetika. 
Bentuk rekonstruksinya yakni mengikuti perkembangan zaman, menyesuaikan dengan desa budaya dan menggunakan seni lukis wayang kopang sebagai media memperkuat sradha dan bhakti.

Kata kunci : rekonstruksi, wayang kopang, hindu

\section{PENDAHULUAN}

Seni lukis adalah salah satu cabang seni rupa, yang telah ada sejak jaman prasejarah, seni itu lahir atas dorongan kreaktifitas Kebudayaan manusia untuk memenuhi kebutuhan hidup material dan spiritual magis menurut kepercayaan pada jaman itu. Seni lukis di Bali merupakan perwujudan karya cipta keindahan manusia dan alamnya yang disajikan ke dalam bentuk dua dimensi yang merupakan olahan ungkapan coretan-coretan, garis yang dipadukan dengan unsur unsur dan prinsip prinsip seni rupa yang harmonis.

Di Desa Kerambitan Tabanan terdapat gaya seni lukis wayang yang sangat unik. Sangat berbeda dengan seni lukis yang lainnya yang ada di Bali. Seni lukis tersebut bernama Seni lukis Wayang Kopang. Gaya seni lukis ini diciptakan bersamaan dengan berdirinya sebuah sanggar bernama Sanggar Kopang pada tahun 1934 oleh Anak Agung Wayan Kopang.

Gaya Seni Lukis Wayang yang ada di Sanggar Kopang ini mempunnyai style khas Lukisan wayang kopang yang dalam visualnya dalam bentuk karakter wujud rupa manusia, binatang, dewa dewi yang sangat tinggi, pewarnaan yang sangat sederhana, namun berkesan gagah perkasa dan agung. Tema seni lukis ini di seputar pewayangan seperti Mahabrata, Ramayana, Tantri yang didalamnya terkandung ajaran agama Hindu. Gaya seni lukis wayang kopang ini merupakan gaya seni lukis tradisional yang unik dari segi wujud rupa dan proses pengerjaannnya.

Seiring perkembangan jaman, berdampak pada menurunnya seni lukis wayang kopang. Bahkan seni lukis ini mengalami keterpurukan di lapangan karena kurangnya peminat, termasuk anak didik yang menekuni dunia seni lukis ini sangat jarang. Melihat situasi tersebut, masyarakat Desa Pakraman Kerambitan Tabanan berupaya untuk membangkitkan lagi gaya seni rupa ini dengan seni rupa yang berbasis Hindu. Hal inilah yang akan dibahas lebih lanjut.

\section{METODE PENELITIAN}

Penelitian ini adalah penelitian kualitatif. Metode dalam pengumpulan datanya yakni dengan cara melakukan observasi terhadap karya-karya seni lukis wayang kopang. Selain itu peneliti juga berupaya melakukan wawancara dengan para pelukis dan tokoh seni rupa wayang kopang. Tidak hanya itu saja, penulis juga berupaya menelusuri dokumen baik dalam bentuk katalog maupun informasi yang berhubungan dengan seni lukis wayang koang ini. Selanjutnya, jika data terkumpul akan dilakukan analisis dan penyajian analisis data.

\section{PEMBAHASAN}

\subsection{Gambaran Umum Seni Lukis Wayang Kopang Desa Kerambitan Tabanan}

Lukisan wayang gaya kopang ini diciptakan oleh Anak Agung Wayan Kopang yang merupakan seniman terkenal di tahun 1930-an, karyanya dibuat dengan sangat cepat mempergunakan kuas sebagai alat untuk menggores, sehingga muncul goresan yang kuat dan sangat ekspressif. Akibatnya detail menghilang, dan muncul bentuk-bentuk baru secara global, dan tampak sederhana. Begitu juga dalam pewarnaannya, menampakan kesederhanaan namun secara totalitas nampak perkasa dan agung.

Terciptanya bentuk seni lukis wayang kopang merupakan sebuah proses pembelajaran yang dilalui oleh penciptanya sehingga mampu menciptakan gaya lukisan yang berbeda unik dari seni lukis lainnya di Bali dengan ciri khas seni lukis wayang kopang, yang didalamnya mengandung tema tema ajaran agama Hindu seperti pewayanan, Tantri dll yang tetap dilestarikan dari dulu hinga masa yang akan 
datang di sanggar kopang desa kerambitan.

Namun seiring perkembangan waktu seni lukis wayang kopang sendiri mulai dilupakan bahkan masyarakat setempat pun tidak mengenal keberadaan seni lukis yang memiliki gaya khas Kerambitan tersebut. Hal ini pernah disampaikan oleh David T, Stuart-Fox dalam tulisannya yang dimuat dalam koran harian Bali Post, Minggu Tanggal 9 Agustus 1981 yang menyampaikan bahwa Anak Agung Wayan Kopang merupakan Cokotnya Kerambitan namun demikian keberadaan beliau terlupakan, hal inilah yang melatar belakangi dibentuknya sebuah sanggar lukis wayang yang diberikan nama sanggar kopang.

Melihat perkembangan seni lukis wayang kopang mengalami keterpurukan, keberadaannya dan bahkan kurang dikenal terlupakan dimasyarakat akhirnya sanggar seni lukis wayang kopang bekerjasama dengan masyarakat swadaya Desa Kerambitan mengadakan rekonstruksi kembali keberadaan seni lukis wayang kopang berbasis seni rupa Hindu tanpa meninggalkan pakem utuh dari gaya seni lukis wayang kopang. Pujiwiyana menyampaikan sanggar adalah suatu wadah, tempat atau perkumpulan baik individu maupun kelompok yang pada umumnya program serta tujuannya demi munculnya ide-ide baru, kemudian dikembangkan sehingga hasilnya dapat disampaikan kepada masyarakat umum dan diterima serta dinikmati.

\subsection{Ideologi Dibalik Rekonstruksi Seni Lukis Wayang Kopang Berbasis Seni Rupa Hindu \\ 3.2.1 Pendidikan}

Faktor yang mempengaruhi rekonstruksi seni lukis wayang kopang adalah tingkat pendidikan. Seorang seniman yang dibekali ketrampilan dan pengetahuan dari sekolah akan lebih dihargai dalam kehidupannya sebagai orang dewasa. Begitu juga sebaliknya jika seniman itu hanya berkutat tanpa pendidikan, pekerjaannya mereka hanya akan terbatas pada ruang lingkup rumah tangga dan tergantung pada kelompok terpencil, dan mereka akan tetap berada di luar sehingga proses pembelajaran pendidikan tidak dapat mempengaruhi kehidupan mereka dalam hidupnya.

Semakin tinggi pendidikan seseorang semakin tinggilah psikologi pengetahuannya akan turut serta mempengaruhi pola pikir sikap dan bertindak (Unesco, 2000 : 72)". Sejalan dengan pendapat ilmuan di atas, wawancara Ida Bagus Ketut Suta tokoh seniman lukis kopang Tanggal 22 April 2020 berpendapat: orang yang memiliki pendidikan artinya mereka telah membuka kesempatan untuk berkembang membangun kehidupannya.

\subsubsection{Identitas}

Rekonstruksi seni lukis wayang kopang di Desa Kerambitan dilandasi oleh ideologi identitas. Penguatan identitas yang dimaksud adalah ciri khas seni lukis wayang kopang sebagai identitas masyarakat di Sanggar Kopang di Desa Kerambitan. Kebudayaan merupakan sebuah situs kontestasi dalam hal tersebut. Kebudayaan berada dalam satu konstruksi dominasi dan hegomoni tertentu, tentunya tidak ada dominasi atau hegemoni yang sempurna. Akan selalu menunjukkan identitas seperti identitas yang dimiliki oleh Sanggar Kopang yaitu seni lukis wayang kopang.

Penguatan identitas ini dilakukan masyarakat Bali akibat gaya baru yang menerapkan pembangunan ekonomi dan modernisasi yang berusaha menciptakan kebudayaan nasional sejak tahun 1970an berlandaskan kebudayaan daerah atau identitas etnis kulturalnya (Picard, 2006 : 240). Dalam prakteknya, identitas etnis tidak hanya dinamis oleh negara tetapi juga dimanfaatkan dalam memberikan sumbangan pada proses kebudayaan nasional. Kebudayaan daerah dianggap sebagai sumber daya potensial untuk unsur budaya kepada kebudayaan nasional Indonesia.

\subsubsection{Kesejahteraan}

Rekonstruksi seni lukis wayang kopang didasari atas semangat memperoleh kesejahteraan atau penghidupan ekonomi bagi para senimannya. Karena salah satu penyebab keterpurukan dan minimnya generasi yang melestarikan model dan gaya seni lukis ini adalah tidak menguntungkan secara ekonomi. Artinya, aspek ekonomi berkorelasi juga dengan eksistensi kesenian di Kerambitan. 
Apalagi selama ini, sebagai destinasi pariwisata yang bersumber dari alam dan kesenian masyarakatnya, masyarakat Bali hidup dari hasil pariwisata dan menjajakan produk kesenian. Hanya saja tidak berdampak pada semua kesenian tergantung dari minat pasar. Kendati demikian, sanggar kopang terus berupaya untuk menghidupkan kembali gaya lukis ini karena merupakan warisan budaya yang menunjukkan ciri khas dan keunikannya tersendiri.

\subsubsection{Pelestarian}

Sebagai salah satu aspek penting, budaya adalah aset yang dimiliki oleh setiap negara, hal inipun berlaku di Indonesia, dengan keberagaman budaya, Indonesia dapat terkenal hingga kancah internasional. Semua negara mengakui dan mengenal Indonesia dari keanekaragaman budaya yang dimilikinya. Keunikan budaya serta tata cara hidup masyarakat yang dilakukan secara berkelompok atau masyarakat yang kemudian diwariskan melalui leluhur secara turun-temurun dari generasi dan regenerasi berikutnya dalam hal ini budaya adalah identitas dari sebuah bangsa. Identitas tersebut tetap harus dijaga dan dilestarikan.

Dalam upaya menjaga dan melestarikan budaya dalam sebuah bangsa perlu peran dari masyarakat yang ada di dalamnya. Sesuai wawancara Wawancara Ida Bagus Ketut Suta (tanggal 28 april 2020) dijelaskan, bahwa rekonstruksi seni lukis wayang kopang di Desa Kerambitan melalui pengajaran melukis wayang kopang dimulai dari tingkat Sekolah Dasar, Sekolah Menengah Pertama dan Atas. Hal ini bertujuan untuk melatih menghidupkan kembali dan melestarikannya sebagai produk budaya lokal jenius Desa Kerambitan.

Saat rekonstruksi pengembangan seni lukis kopang diterima oleh anak muda maka akan mulai muncul rasa kepemilikan. Rasa kepemilikan ini muncul setelah anak-anak muda dilibatkan langsung, dilatih dalam suatu wadah untuk memperkenalkan dan memperdalam mempelajari ilmunya. Ketika mereka mengetahui bahwa seni lukis wayang kopang dapat dipelajari dan dilatih secara mendalam. Maka saat itulah generasi muda ini secara otomatis sudah ikut berpartisipasi sebagai pelestarian budaya.

\subsubsection{Estetika Hindu}

Djelantik (1999;3) menjabarkan estetika sebagai ilmu yang mempelajari segala sesuatu yang berkaitan dengan keindahan dan aspek dari apa yang disebut indah'. Lebih lanjut dijelaskan bahwa keindahan suatu objek dapat dikaji melalui 3 aspek utama yaitu aspek wujud/rupa, bobot/isi, dan penyajian/penampilan. Wujud menyangkut bentuk (unsur yang mendasar) dan struktur/susunannya. Bobot menyangkut bukan apa yang dilihat semata, namun dirasakan sebagai makna dari wujud. Bobot menyangkut suasana (mood), gagasan (idea), dan pesan (message). Sementara penampilan menyangkut cara penyajian karya kepada pemerhati atau penikmat. Penampilan sangat dipengaruhi oleh bakat (talent), keterampilan (skill), dan sarana (media).

Kajian estetika senantiasa berhubungan dengan seni. Dengan demikian kesenian dapat dikatakan merupakan salah satu unsur yang mengandung rasa keindahan atau estetika. Adapun estetika yang dilihat dari pandangan Agama Hindu merupakan pandangan mengenai rasa keindahan yang diikat oleh nilai-nilai Agama Hindu yang didasarkan atas ajaran-ajaran kitab suci Weda. Ada beberapa konsep yang kiranya menjadi landasan penting dari Estetika Hindu. Konsep-konsep yang dimaksud antara lain "konsep kesucian, konsep kebenaran, dan konsep keseimbangan (Dibya, 2003 : 96)".

Karya seni bisa dipandang sebagai sabda, karena diciptakan berdasarkan tujuan tertentu dengan maksud menyampaikan sesuatu berupa lambang atau simbol. Di Bali mulai dari peradaban seni rupa purba yang terlihat dari jaman prasejarah hingga kini memuja Tuhan dalam manifestasi sebagai seniman lukis, hias, tukang gambar disebut Bhatara Citrakara sebagai manifestasi sekaligus pencipta seni rupa yang Maha Agung. Konsep kesucian (shiwam), mencakup nilai-nilai ketuhanan yang juga mencakup yadnya dan taksu.

Hal ini memiliki pandangan estetik yang diikat oleh nilai-nilai spiritual ketuhanan sesuai dengan ajaran agama Hindu, konsep kebenaran (satyam) mencakup nilai kejujuran, ketulusan, dan 
kesungguhan, sesuai dengan ajaran agama Hindu yadnya yang dilakukan oleh masyarakat Hindu seyogyanya dilaksanakan dengan penuh kejujuran hati, rasa tulus, dan niat yang sungguhsungguh.

Konsep keseimbangan (sundharam), mencakup persamaan dan perbedaan dalam beberapa dimensi, identik dengan istilah $R w a$ Bhineka, sekala-niskala adalah dua unsur yang selalu ada dan saling mempengaruhi. Terkait dengan pandangan ilmuan di atas rekonstruksi Seni lukis Wayang Kopang terlihat jelas konsep idiologi estetika Hindu tergarap didalamnya mulai dari wujud internal karya dari segi konsep, ide dan gagasan bernuansa Hindu, dan wujud eksternal karya mulai dari penciptaan hinga sampai proses rekonstruksi yang terjadi dalam karya seni lukis wayang kopang masa kini. Estetika Hindu inilah yang menjadi sebuah landasan idiologi untuk membuat sebuah karya sebagai perlambang atas kebenaran simbol simbol ketuhanan.

\subsection{Bentuk Rekonstruksi Seni Lukis Wayang Kopang Berbasis Seni Rupa Hindu}

\subsubsection{Mengikuti Perkembangan Jaman}

Perkembangan jaman dapat diartikan sebagai turut serta melakukan sesuatu sesuai dengan perubahan jaman. Hal ini dapat diidentikan sebagai sikap yang tidak lagi memegang prinsip-prinsip tradisional, namun lebih cenderung untuk menyesuaikan diri dengan tuntunan jaman, ideologi modern. Ini menunjukkan kecenderungan akan adanya kebebasan serta tidak adanya aturan dalam tatanan sosial.

Si pelukis mendobrak dan mendekonstruksi wacana-wacana ketimpangan seni lukis di dalam masyarakat dengan menampilkan kedinamisan sebuah ideologi seni lukis berupa munculnya ideologi khas seni lukis kopang mengikuti perkembangan jaman. Sesuai [wawancara Ida Bagus Ketut Suta tanggal 28 April 2020], para pelukis sekarang mulai mendekonstruksi pewarnaan wayang dengan warna modern tetapi pakem tetap still gaya kopang bernafas ajaran hindu agar keliatan lebih menarik penikmat. Seperti terlihat gambar berikut ini;

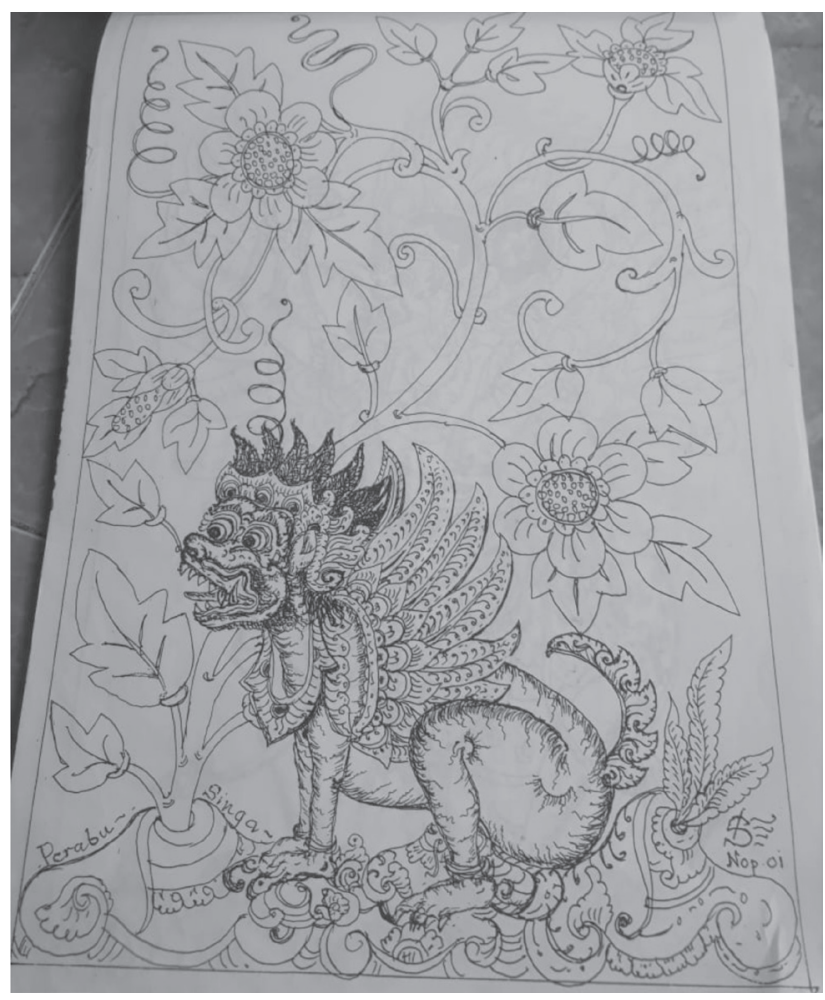

Judul : Lukisan Kekarangan Singa. Karya I Wayan Surata Dokumentasi : I Kadek Sumadiyasa tanggal 28 Juni 2020

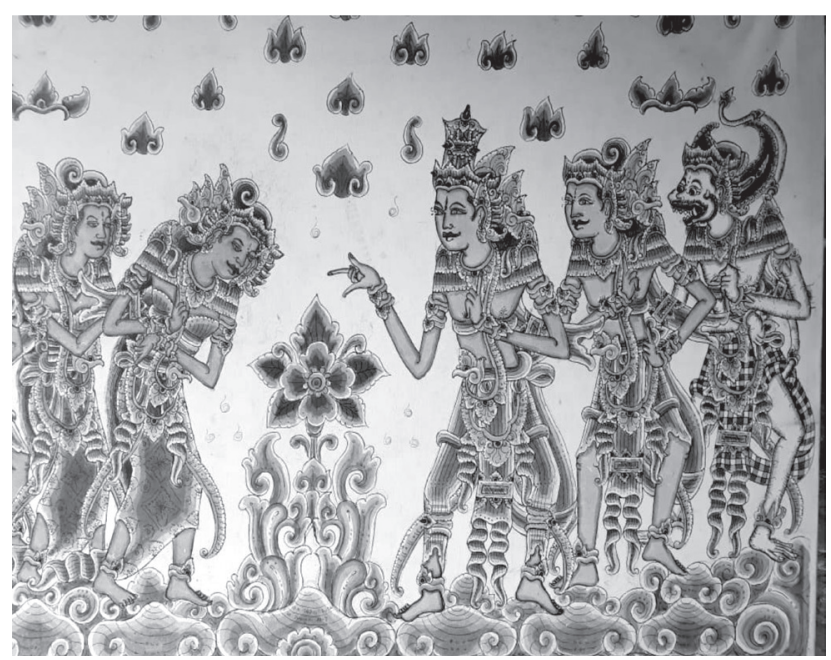

Judul : Sewa Mara, Karya Ida Bagus Ketut Suta Dokumentasi : I Kadek Sumadiyasa tanggal 28 Juni 2020

\subsubsection{Seni Lukis Wayang Kopang Menuju Wisata Desa Budaya}

Menurut pernyataan Richards (1996:266)."Bahwa kecenderungan pariwisata budaya global ditandai dengan meningkatnya bentuk-bentuk pariwisata posmoderat, yang terkait dengan seni budaya di desa". Pariwisata posmoderat sangat berhubungan dengan citra (image) demi otensitas dan dengan pasar dan 


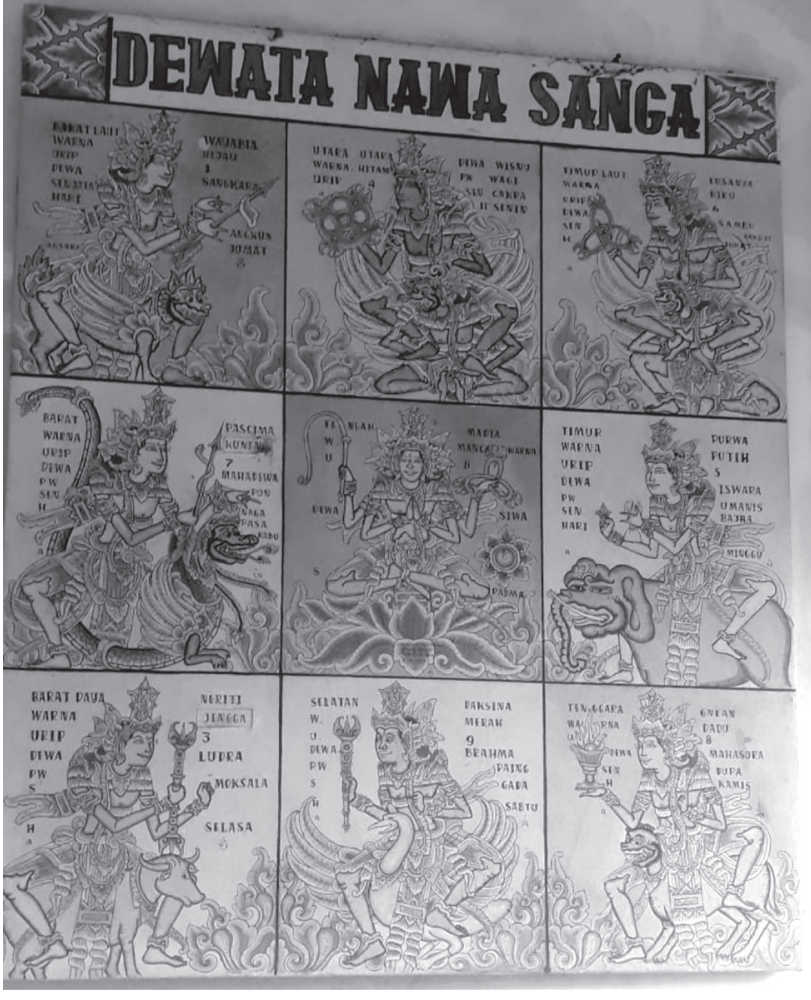

Judul : Pelelintangan, Karya Ida Bagus Ketut Suta Dokumentasi : I Kadek Sumadiyasa tanggal 28 Juni 2020

pospordis sebagai sesuatu yang berbeda satu pola-pola produksi yang mengikuti pasar. Konsumsi pariwisata budaya oleh wisatawan pos moderent berhubungan dengan kelompok sosial tertentu (certain social groups) dan secara khusus dengan kelas menengah baru (now middle class), banyak analisis tentang meningkatnya konsumsi pos moderent di dasarkan karya sosiologi Perancis Pierre Bourdiev yang menyatakan bahwa perjuangan kelas-kelas sosial berusaha untuk membuat perbedaan antara dirinya dan orang lain melalui pendidikan, pekerjaan, dan konsumsi komoditas dimana hal ini juga mencangkup konsumsi pariwisata.

"Kombinasi yang terakumulasi dari modal sosial, pendidikan, dan budaya dari kelompokkelompok sosial tertentu membentuk habitus atau budaya kelas (class culture) yang berbeda". (Richards, 1996:266).

Sebagai bagian dari pariwisata pos modern, pengembangan Dekonstruksi seni lukis wayang kopang di Desa Kerambitan menuju wisata budaya Keagamaan hindu, terkait bentukbentuk gaya seni lukis yang unik dan berbeda dari yang lainnya, dimana dalam bentuk-bentuk tersebut dilakukan langkah Dekonstruksi yang berdampak pada nilai budaya dan ekonomi secara langsung. Mengacu pada sejumlah pakar, Richards (1996 : 266) menekankan bahwa" modal budaya (cultural capital) tidak hanya dapat digunakan sebagai cara-cara untuk membedakan personal (manusia) tetapi dapat juga dapat mencirikan tempat (palace)". Dalam rangka menarik modal investasi dan juga menarik daya beli para kelas menengah tersebut, bentuk-bentuk yang tinggi dan pewarnaan moderen dalam seni lukis wayang Kopang ini mampu membedakan dirinya dengan menekankan kualitas estetika dari komoditas material dan pelayanannya yang mempresentasikan modal simbolik budaya hindu di desa kerambitan.

Sekaligus sebagai tindakan Dekonstruksi budaya guna kepentingan pariwisata. Dalam [wawancara I wayan surata dan made rukun tgl 28 april 2020] menambahkan perlunya upaya dekonstruksi seni lukis wayang kopang sebagai wisata desa budaya berbasis kehinduan, seperti dibawah ini:

"wisata budaya desa basis kehinduan, karena dalam gambar bentuk seni wayang kopang unik yang direkonstruksi kembali dengan warna modern tetapi pakem utuh tetap seperti semula berarti menaikkan kembali nilai estetik wayang lukis itu sebagai obyek etnis wisata budaya di desa kerambitan".

Senada paparan diatas menurut Dinas Tata Kota dan Tata Bangunan di Kabupaten Tabanan 2003 adalah "tindakan mengamankan, melindungi, memelihara, dan memanfaatkan seni lukis wayang kopang sebagai budaya wisata di desa suatu produk baru".

Strategi pengembangan Dekonstruksi seni lukis wayang kopang berbasis Wisata budaya bercorak hindu, desa sebagai contoh bentukbentuk wayang kopang serta nama pendiri dan pencipta dari lukisan ini sampai sekarang dinamakan seni lukis wayang kopang. Seperti terlihat gambar dibawah ini: 


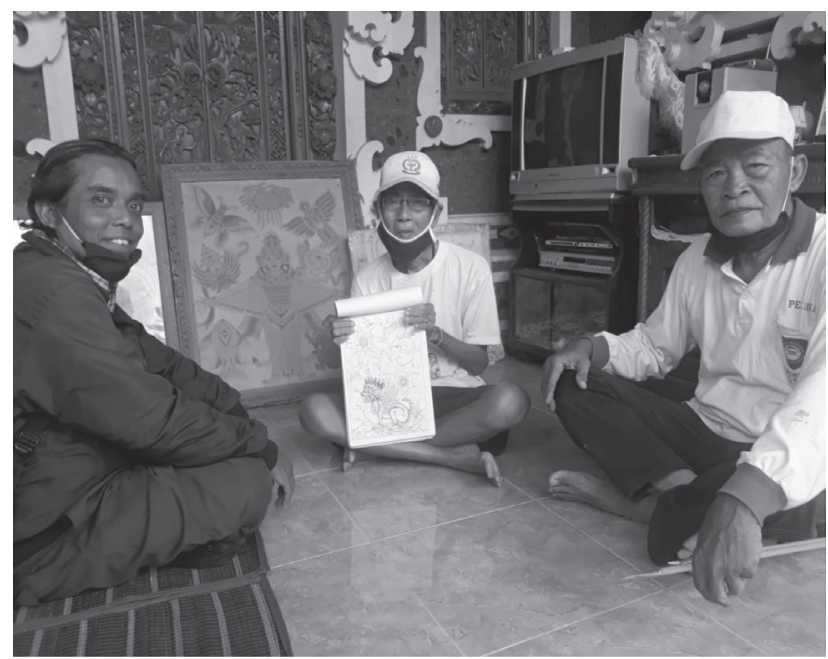

Wawancara peneliti dengan tokoh lukis I Wayan Surata dan I Made Rukun / Pelukis Wayang Kopang

Dokumentasi : I Kadek Sumadiyasa tanggal 28 Juni 2020

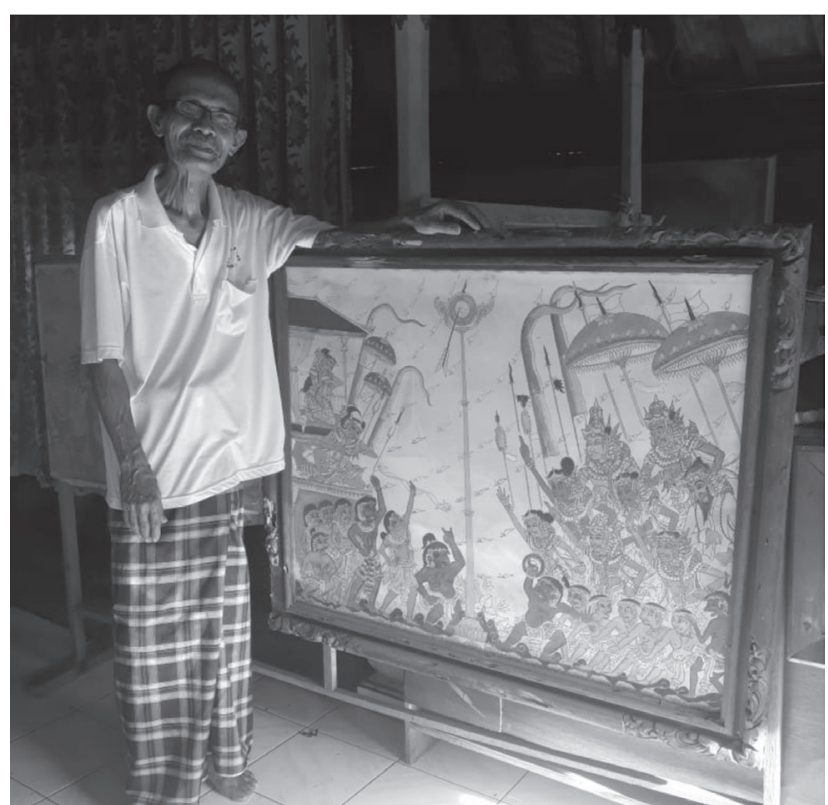

Judul Karya Perang Bharata Yuda : Pemeran di Jero Marga Kerambitan Pelukis Anak Agung Made Sukadana Dokumentasi : I Kadek Sumadiyasa tanggal 28 Juni 2020

\subsubsection{Pameran Seni Lukis Wayang Kopang}

Menurut ilmuan Jim Supangkat kurator besar seni rupa Indonesia mengatakan, pameran adalah sebuah kegiatan ajang prestasi penyajian karya seni rupa untuk diinterpretasikan, disajikan khalayak umum/publik sehingga berhak untuk di apresiasi oleh masyarakat luas. Dalam pameran ini sang seniman berhak untuk menyampaikan pesan kritik dan saran kepada audien untuk dibaca, diterjemah dalam bahasa ungkap. Gagasan ide yang tertuang melalui karya seni, sehingga di dalam pameran ini diharapkan terjadi komunikasi respon stimulus pembelajaran dari pembacaan hanya yang diwakili oleh media karya seni sebagai peneliti karakteristik jati diri si seniman. Seperti terlihat gambar dibawah ini;

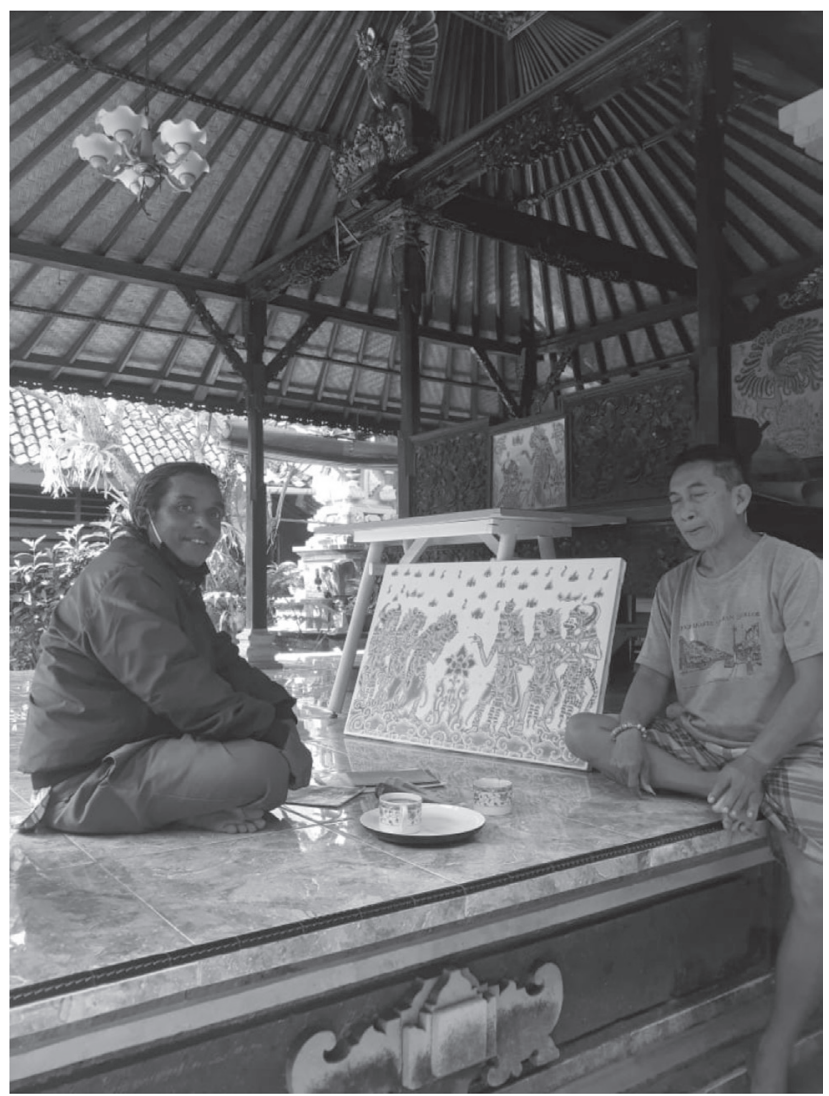

Wawancara Seniman Ida Bagus Ketut Suta dengan I Kadek Sumadiyasa / Peneliti

Dokumentasi : I Kadek Sumadiyasa tanggal 28 Juni 2020

Menurut [wawancara tanggal 30 Januari 2020 Ida Bagus Ketut Suta] keluarga seniman lukis Sanggar Kopang, menjelaskan pameran yang pernah dilakukan oleh Sanggar Kopang adalah pameran Swadaya yang dibiayai oleh Sanggar Kopang di taman budaya sertakerjasama pameran-pameran di Pesta Kesenian Bali. Dari pameran pameran ini diikuti oleh pelukispelukis di Sanggar Kopang bertujuan untuk memperkenalkan produknya sebagai sebuah rekonstruksi yang bersifat baru dengan tujuan supaya terkenal sepanjang jaman. Seperti terlihat gambar dibawah ini: 

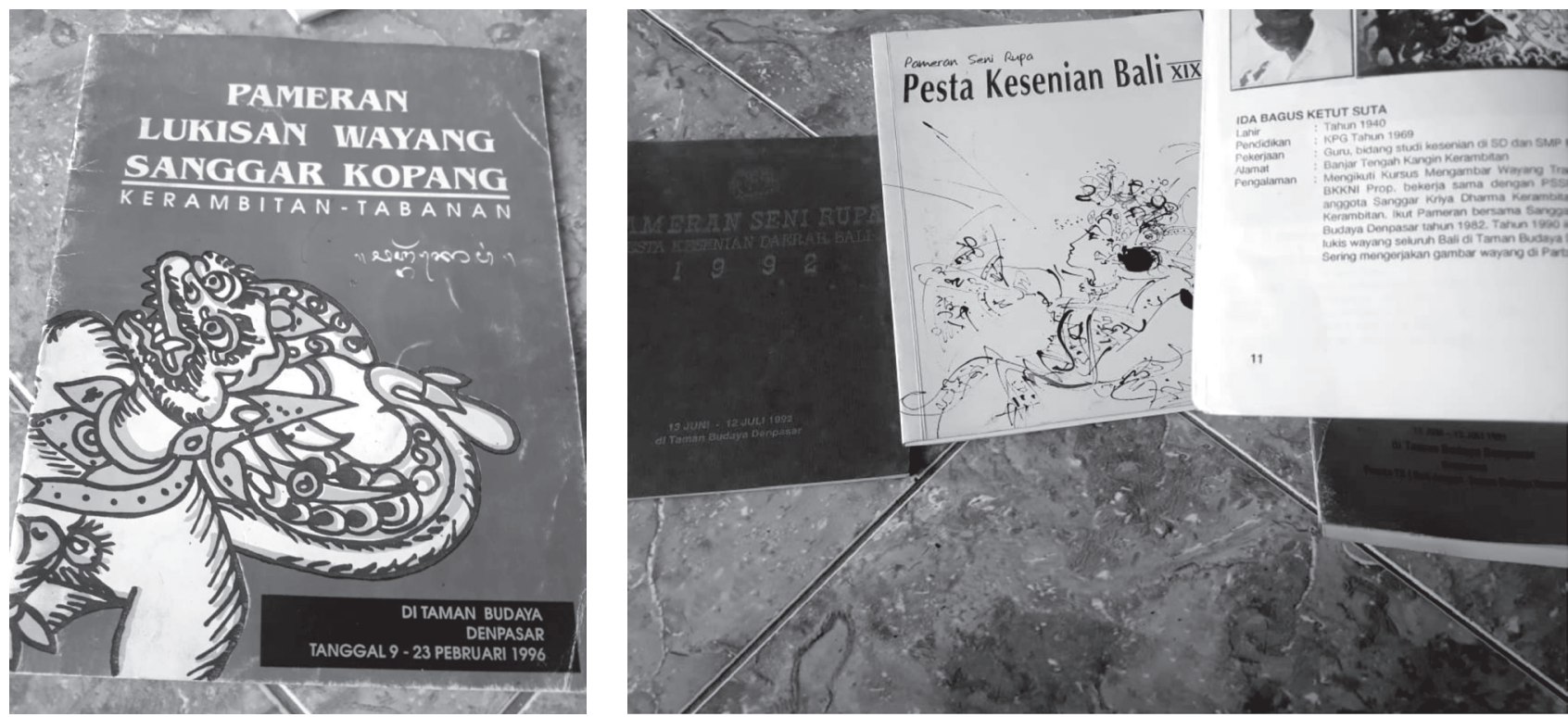

Katalog Pameran Seni Lukis Wayang Kopang Kerjasama dengan Pesta Kesenian Bali Dokumentasi : I Kadek Sumadiyasa tanggal 28 Juni 2020

Menurut Anak Agung Gede Sukadana (wawancara tanggal 30 April 2020) adalah pameran swadaya dikemas secara berkelompok dengan anggota Sanggar Kopang yang dibiayai oleh swadaya pribadi masing-masing pelukis kopang di Kerambitan maupun di taman budaya Denpasar. Dimulai dari perencanaan sampai pemajangan dikerjakan oleh keluarga seniman lukis kopang. Dari Pameran seniman di atas para pelukis sanggar kopang sangat antusias mengikuti pameran tersebut sebagai pengembangann keilmuan yang bertujuan untuk melestarikan seniman pelukis wayang kopang supaya tetap terkenal di masyarakat luas. Berikut penjelasannya: "Seni lukis wayan kopang pernah dipamerkan di Pesta Kesenian Bali dengan kerjasama provinsi Bali. Saat itu pameran seni lukis kopang mendapat apresiasi penonton sebagai seni lukis bergaya khas/unik. Pameran ini bertujuan untuk menghidupkan kembali melestarikan seni lukis wayang kopang".

\subsubsection{Pameran Tetap di Jro Marga Banjar Tengah Desa Kerambitan}

Salah satu bentuk rekonstruksi seni yang dilakukan kembali untuk tujuan menyelamatkan karya karya style Anak Agung Kopang dilakukan dengan mengadakan pameran tetap. Selain pameran bekerjasama dengan Pesta Kesenian Bali, Jro Marga adalah tempat pameran tetap koleksi pelukis style gaya Anak Agung Wayan Kopang yang masih banyak dikunjungi pengunjung hingga kini baik dari kalangan pendidikan, peneliti, maupun wisatawan. Karya yang disajikan merupakan kumpulan pelukis bimbingan dari Anak Agung Wayan Kopang beserta anak didik dan keluarganya.

Sesuai wawancara Anak Agung Made Sukadana tanggal 28 Mei mengatakan bahwa pihaknya tetap melakukan pameran tetap di Jro Marga Kerambitan diikuti oleh keluarga seniman di Jro Marga, dan kelompok pelukis pelukis sanggar kopang bimbingan Anak Agung Wayan Kopang bergaya style seni lukis wayang kopang yang bertujuan untuk membangkitkan kembali pengembangan budaya seni lukis wayang kopang. Seperti terlihat gambar di bawah ini; 

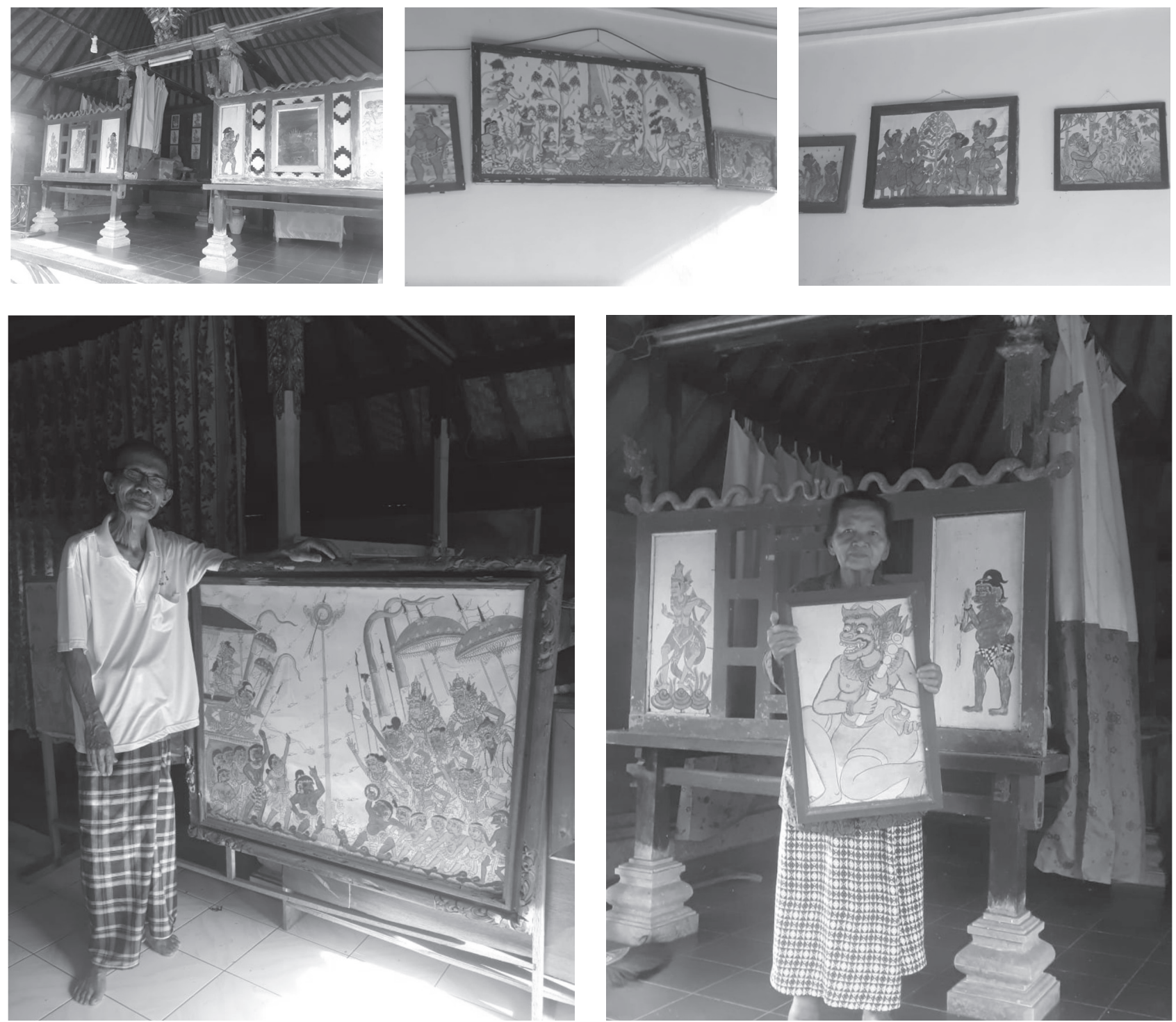

Pameran Tetap Seni Lukis Wayang Kopang di Jero Marga Kerambitan Tabanan Dokumentasi : I Kadek Sumadiyasa tanggal 28 Juni 2020

Dari pemaparan informan diatas dapat disimpulkan bahwa seni lukis wayang kopang direkonstruksi kembali dengan cara melakukan sebuah ajang pameran tetap di Jro Marga Kerambitan untuk menjaga kelestarian dan eksistensinya sebagai gaya lukis yang unik dan memiliki identitas tersendiri.

\subsubsection{Menerima Kunjungan dari Lembaga Pendidikan dan Wisatawan}

Keberadaan perguruan tinggi dalam suatu negara berperan sangat penting dalam menerapkan Tri Dharma Perguruan Tinggi, yang bertujuan untuk menciptakan lulusan mahasiswa yang berpendidikan dan berguna, tidak hanya untuk dirinya sendiri, namun juga berguna untuk masyarakat Indonesia melalui pendidikan, penelitian dan pengabdian masyarakat. Tri Dharma Perguruan Tinggi tercantum dalam Undang-Undang No. 20 Tahun 2003 yaitu tentang sistem pendidikan nasional menyebutkan bahwa perguruan tinggi berkewajiban untuk menyelenggarakan pendidikan, penelitian dan pengabdian masyarakat.

Terkait dengan landasan peran serta peraturan perundang-undangan perguruan tinggi di atas Sanggar Seni Lukis Kopang banyak menerima kunjungan dari dunia pendidikan di perguruan tinggi di Bali, seperti yang dikatakan 
pada \{wawancara Anak Agung Made Sukadana Tgl 28 April 2020\}

"Sanggar Seni Lukis Kopang siap menerima dari berbagai kunjungan di dunia pendidikan dari sekolah TK, SD, SMP, SMK, Perguruan Tinggi yang berfungsi sebagai edukasi pendidikan sebagai sumber ilmu pengetahuan. Kami berharap seni lukis kopang supaya terkenal bisa diterima di kalangan pelajar maupun umum."

Ada beberapa perguruan tinggi di Bali yang mengadakan sebuah penelitian di Sanggar Kopang seperti ISI Denpasar seperti yang dikatakan oleh Anak Agung Gede Sukadana (wawancara Tanggal 22 Februari 2020) sebagai berikut :

"Sanggar Kopang menerima kunjungan dari kampus ISI Denpasar. mengadakan kerjasama dengan Sanggar Kopang dan Pemkab Tabanan mengadakan penelitian tentang seni lukis Wayang kopang secara umum".

Dari pengalaman yang didapat dalam kerjasama ini para seniman kopang berharap kampus ISI Denpasar maupun kampus yang lain di Bali untuk turut serta ikut melestarikan seni lukis kopang ini sebagai warisan leluhur dari Desa Kerambitan sebagai seni lukis yang unik, dimana keluarga Sanggar Kopang menerima terbuka setiap ada kunjungan dari lembaga maupun pendidikan tinggi.

Senada dengan Sukadana, Ida Bagus Ketut Suta (wawancara tanggal 22 Februari 2020) mengatakan sebagai berikut "Kami juga banyak mengajar tamu-tamu lokal maupun luar Bali/ wisatawan terkait seni lukis kopang. Biasanya tamu dari perguruan tinggi luar negeri lebih banyak meneliti tentang ciri-ciri karakter dari seni lukis kopang. Dari segi bentuk dan penokohan dari wujud-wujud pewayangan". Karena menurut pengakuan wisatawan tersebut wayang kopang sangat berbeda dengan tokoh wayang lainnya di Bali.

Wisatawan tersebut meminta kepada pelukis kopang untuk tetap mempelajari gaya seni lukis kopang ini sebagai bentuk pelestarian budaya bahwa gaya ini memang unik. "Sanggar lukis wayang kopang melakukan melakukan pelatihan pelatihan, worshop melukis wayang kopang dengan warna modern namun tidak menghilangkan pakem kekunoannya yang dilaksanakan di sanggar kopang, sekolah SD,SMP yang dibina oleh Anak Agung Cidra di Desa Kerambitan".

Dari pemaparan wawancara di atas dapat diuraikan bahwa Sanggar Seni Lukis Wayang Kopang di Desa Kerambitan sudah cukup besar komitmennya untuk melestarikan kembali dengan mengadakan kerjasama di bidang pendidikan seni dengan beberapa lembaga pendidikan dari TK, SD, SMP, Perguruan Tinggi dalam maupun luar negeri. Sebagai wujud untuk melestarikan kembali seni lukis kopang sebuah karya seni yang unik yang tidak ada di daerah lain yang sangat penting untuk dikembangkan dan dipertahankan.

\subsubsection{Menggunakan Karya Seni Lukis Kopang Sebagai Ungkapan Srada Bakti}

Dalam mendekatkan diri kehadapan Ida Sang Hyang Widhi Wasa pelaksanaan bhakti marga merupakan salah satu jalan yang ditempuh oleh umat Hindu di Desa Pekraman Kerambitan, yaitu melalui pengabdian tulus iklas yang lahir dari rasa cinta kasih. Melalui rasa bakti yang tulus iklas umat Hindu di Desa Pekraman Kerambitan mewujudkan rasa bakti mereka melalui pelaksanaan yadnya. Pelaksanaan yadnya ini misalnya melalui pembuatan sarana upacara keagamaan di pura yang bersifat utama yang berbentuk karya seni rupa berwujud iderider dan wastra pelinggih pura. Dihaturkan pada saat odalan di pura. Rasa bhakti kehadapan Ida Hyang Widhi Wasa jika dilandasi dengan atas kesucian hati, rela berkorban dengan penuh keiklasan akan dapat mengetahui dan menyatakan diri kepada Tuhan. Hal ini jelas diuraikan dalam Kitab Bhagawad Gita XVIII-55 sebagai berikut :

\section{Bhaktya mam abhijanati \\ Yayan yas ca sini tatvatah \\ Toto man tatvato jnatva \\ Visate tadanantaran}

\section{Artinya :}

Dengan jalan mengabdi ia mengetahui aku

Berapa agung dan siapa aku sebenarnya 
dan

Setelah mengetahui aku yang sesungguhnya,

Ia kemudian masuk ke dalam ku (Mantra,1996 : 251)

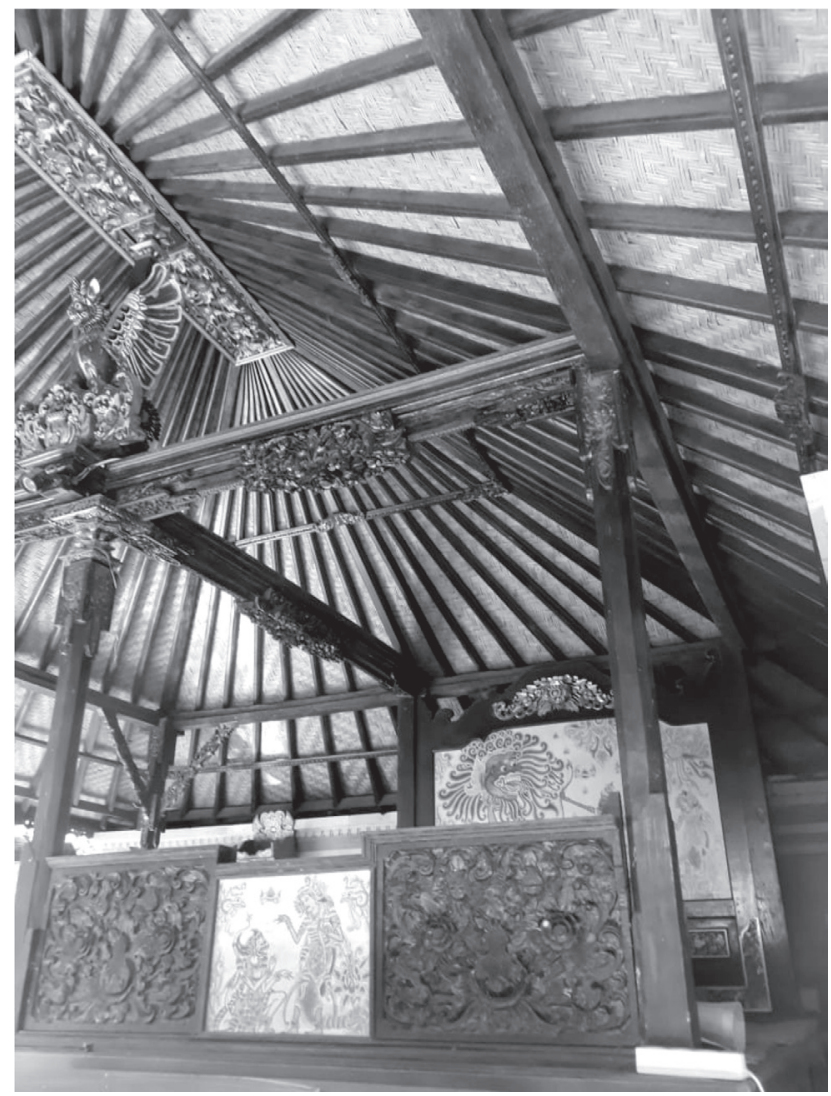

Lukisan Parba di Griya Ida Bagus Suta

Dokumentasi : I Kadek Sumadiyasa tanggal 28 Juni 2020

Uraian sloka di atas ternyata memberikan petunjuk bahwa dengan pengabdian dan rasa bhakti kehadapan Ida Sang Hyang Widhi Wasa, umat Hindu dapat menghubungkan diri kehadapan beliau dalam bentuk sarana upacara keagamaan. Hal ini terbukti pada saat pelaksanaan acara upacara dalam pura merajan gede geria babakan kerambitan setempat di warga Kerambitan. Rasa bhakti yang ditunjukkan oleh salah seorang warga pelukis kopang menghaturkan karya lukis di geria gede babakan kerambitan sebagai Parba ulon bale pemujan dengan rupa seni lukis wayang kopang sesuai wawancara dibawah ini (Ida Bagus Ketut Suta, wawancara tanggal 10 April 2020).

"Semenjak saya menjadi pelukis menekuni lukisan wayang kopang ini saya menghaturkan karya seni lukis saya di Geria Gede Babakan Kerambitan berwujud parba bergambar keindahan seni lukis pewayangan kopang, sehingga saya sangat berbangga sekali dan iklas sebagai rasa bakti saya kehadapan ida betara leluhur di Merajan Agung Babakan"

Seperti terlihat gambar dibawah ini;

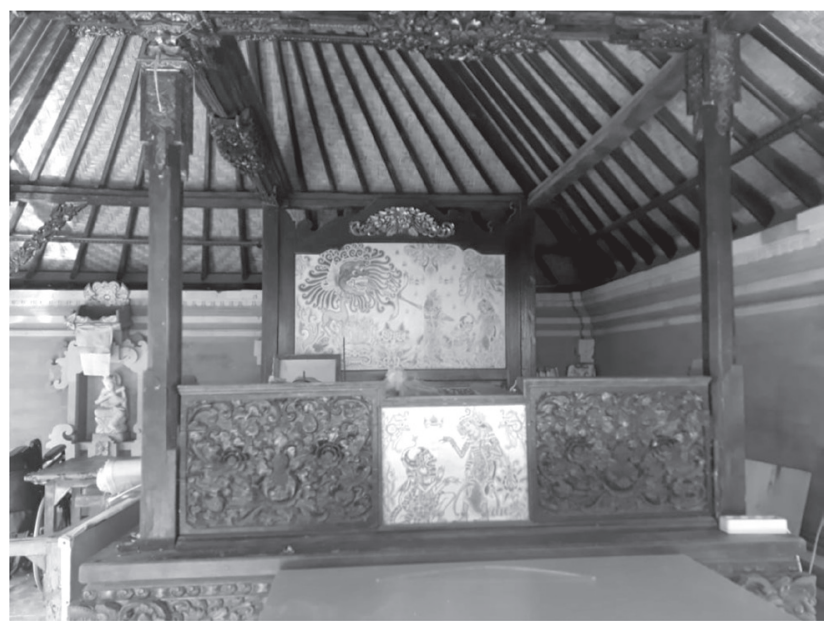

Lukisan Parba di Griya Ida Bagus Suta Dokumentasi : I Kadek Sumadiyasa tanggal 28 Juni 2020

Dari uraian di atas dapat disimpulkan warga Sanggar Kopang yang ada di Desa Kerambitan selama ini mempunyai kemampuan melukis wayang kopang sudah banyak yang dihaturkan ke pura-pura sebagai ungkapan rasa bhakti mereka kehadapan bhetara leluhur berwujud ider-ider pelinggih, wastra pelinggih dan lainlain. Sesuai yang tersirat dalam kitab suci Bhagawad gita Bab X111-55 menyebutkan;

Yana dana tapah harana

Na tyajam karyam eva tat

Yajno danam tapak caiva

Paya nami manishinam

\section{Artinya :}

Mengadakan upacara sedekah dan tapa brata jangan diabaikan melainkan harus dilakukan sebab upacara sedekah serta tapa brata adalah pencuci bagi orang arif bijaksana (Mantra,1996:236).

Sesuai sastra di atas pengungkapan yadnya 
sangatlah penting merupakan wujud sradha bakti umat kehadapan leluhur dalam berbagai bentuk yadnya yang dilandasi rasa yang tulus iklas. Terkait penelitian ini wujud Srada bakti dari para pelukis pelukis sanggar kopang mengaplikasikannya dalam bentuk karya seni parba yaitu ulon bale sebagai karya seni rupa berbasis religius Kehinduan.

\section{PENUTUP}

Ideologi di balik upaya rekonstruksi seni lukis wayang kopang berbasis seni rupa Hindu di Sanggar Kopang Desa Kerambitan yaitu pendidikan melahirkan pendewasaan diri serta perkembangan pengetahuan, ekonomi menyusun tingkat struktur otonom sosial budaya kerambitan, identitas memuncukan etnis kultural khas seni lukis wayang kopang, ideologi kesejahteraan sebagai peningkatann kesejahteraan tarap hidup seniman, ideologi pelestarian yakni melestarikan ajaran melukis wayang kopang di sangar kopang dan disekolah sekolah dll, idiologi Estetika Hindu dalam berkarya berlandaskan Satyam, Sivam, Sundaram. Bentuk Rekonstruksi seni lukis wayang kopang berbasis seni rupa Hindu seperti mengikuti perkembangan jaman dengan memakai pewarnaan moderen, seni lukis wayang kopang menuju wisata desa budaya, pameran seni lukis wayang kopang, pameran tetap di Jro Marga Banjar Tengah Desa Kerambitan, menerima kunjungan dari lembaga pendidikan dari TK hingga perguruan tinggi dan wisatawan, menggunakan karya seni lukis kopang sebagai ungkapan srada bakti seperti lukisan parba.

\section{DAFTAR PUSTAKA}

Althusser, Louise, 2001. Lenin an Philsophy and Other Essays. New York : New York Post.

Bogdan Hr dan Biklen S.K.1982. Qualitatife Research or Education a Introduction toTeory and Methodds. Boston Allyn and Balon Inc[4]

Dibya I Wayan,2003. Sivam,Satyam,Sundaram, Denpasar;Paramita

Djelantik AA.1999. Estetika sebuah pengantar.Denpasar ;Paramita

David T.1981. Stuart-Fok. Denpasar;Bali Post

Jim Supangkat .1999. Buku Galery Nasional Indonesia.Jakarta;Galnas

Endarswara, 2013. Metodologi Penelitian Kebudayaan, Yogyakarta : Gajah Mada University Press. Kamus Besar Bahasa Indonesia, 2003. Tim enyusun Kamus Besar Bahasa Indonesia 2003. Jakarta;

Balai Pustaka

Mantra. 1996. Landasan Kebudayaan Bali. Denpasar: Yayasan Dharma Sastra.

Mulyono,1978.Transformasi nilai nilai pendidikan dalam karya seni.Jakarta; Jakarta Ekspres

Marzuki,2012. Pendidikan Karakter.Bandug;Alfabeta

Pemkab Tabanan.2003. Konsep pelestarian umum Dinas Tata Kota dan Tata Bangunan di Kabupaten Tabanan.Tabanan;Pemkab Tabanan.

Pemkab Tabanan 2009. Peraturan Perundang Undangan No 11 Tahun 2009 tentang Kesejahteraan Masyarakat.Tabanan; Pemkab Tabanan.

Milles Huberman A,Miltes.1992. Analisis Data Kualitatif.Jakarta;Unifersitas Indonesia.

Richards, Greg. 1996. "Production and Consumption of European Cultural Tourism" dalam Anals of

Tourism Research Volume 23 number 2, hlm. 261-283.

Ricards, Michael, 2006. Bali : Pariwisata Budaya dan Budaya Pariwisata, Jakarta : Gramedia.

Unesco, 2000. Gender Sensitivity. Prance ; Ag21 communication

Yosuf Boimar.2017.Sistim etnis kesenian masyarakat etnis.jakarta; Universitas indonesia 


\section{DAFTAR INFORMAN}

1. Nama : Ida Bagus Ketut Suta

Umur : 50 tahun

Pekerjaan : Guru, Ketua Sanggar Kopang,Seniman Lukis Kopang

Alamat : Banjar Tengah Desa Kerambitan

2. Nama : Anak Agung Made Sukadana

Umur : 55 tahun

Pekerjaan : Penglingsir Jro Marga, Seniman Lukis Kopang

Alamat : Jro Marga Banjar Tengah Kerambitan

3. Nama : I Wayan Surata

Umur : 60 tahun

Pekerjaan : Guru, Seniman Lukis Kopang

Alamat : Banjar Tengah Desa Kerambitan

4. Nama : I Made Rukun

Umur : 52 tahun

Pekerjaan : Seniman Lukis Kopang

Alamat : Banjar Tengah Kerambitan 